\title{
The Development of Population Potential and National Power by Elevating the Professional Standard for Sport Coaches
}

\author{
Kittisak Jermsittiparsert ${ }^{1,3}$ \& Thanaporn Sriyakul ${ }^{2,3}$ \\ ${ }^{1}$ Department of Political Science, College of Government and Public Governance, Rangsit University, Thailand \\ ${ }^{2}$ Department of Management, Faculty of Business Administration, Mahanakorn University of Technology, \\ Thailand \\ ${ }^{3}$ The Political Science Association of Kasetsart University, Thailand \\ Correspondence: Kittisak Jermsittiparsert, Department of Political Science, College of Government and Public \\ Governance, Rangsit University, Thailand; The Political Science Association of Kasetsart University, Thailand. \\ Tel: 66-8-6622-2495. E-mail: kittisak.j@rsu.ac.th
}

\author{
Received: February 13, 2014 Accepted: March 19, 2014 Online Published: April 29, 2014 \\ doi:10.5539/ass.v10n10p188 URL: http://dx.doi.org/10.5539/ass.v10n10p188
}

\begin{abstract}
As "population" is the most important potential factor among the sources of "national power", under the circumstances of people suffering from unhealthy conditions stemmed from lack of exercise, reviewing the experiences of superpowers Australia and the United States of America has thus been chosen as the purpose of research, and, therefore, derived the proposal of a research on approaches to elevate "professional standards" for "sport coaches" through Thailand's relevant agencies, particularly the Department of Physical Education, Ministry of Tourism and Sports, as the primary conditions in developing population potential, which would lead to the national power in the long run.
\end{abstract}

Keywords: population potential, national power, professional standard for sport coaches

\section{1. "Population" and "National Power"}

Generally speaking, power is the ability to influence the behviour of people in order to achieve one's intended results (Couloumbis \& Wolfe, 1982, p. 64; Cangemi, 1992, p. 499; Spanier \& Wendzel, 1996, p. 128; Center for Strategic and International Studies, 2007, p. 6). A concept that has been widely accepted in aspect of Political Science of this technical term has been defined by Max Weber (1864-1920), a German sociologist, in a context of a social reaction as the probability that one actor within a social relationship will be in a position to carry out his own will despite resistance, regardless of the basis on which this probability rests. (Weber, 1978, p. 53; cited in Warren, 1992, p. 19).

"National power", which essentially is derived from a basis associated with the ability to kill (others) and protect (oneself) from being killed (Hwang, 2008, p. 3), in a similar sense, is the ability to influence the behaviour of other nations (Kugler \& Tamen, 2004, p. 38), or, in another sense, "national capability", which is the sum of all capabilities available to a nation at a particular time to support in the pursuit of national objectives internally and externally until successfully achieved, notwithstanding some hindrances in-between (Mattos, 1977, p. 129; cited in Kelly, 1984, p. 447).

Historically, such power or capability could be primarily measured and/or defined by three potential elements, a nation's geographical and strategic location (size (vast) topography (suitable) location (ideal) and climate (enabling)), natural resource capability, ((food and raw materials (Sandhu, 2009)), and manpower (quality and quantity) (Wongsurawat, 2007, pp. 145-148; 2554, pp. 127-130; Jablonsky, 2010, pp. 126-129).

In conjunction with other secondary aspects, such as, economic growth and strength (Knorr, 1956; Kugler \& Tamen, 2004) (national income (Davis, 1954; Organski, 1958), gross national product (Hitch \& McKean, 1960), and industrial capacity (Sandhu, 2009)), military force (Claude, 1962; Deutsch, 1968) (military expenditures (Alcock \& Newcombe, 1970), maritime force (Modelski \& Thompson, 1987), and nuclear capability (German, 1960)), as well as social stability (Center for Strategic and International Studies, 2007).

Nevertheless, it has been generally accepted in the modern days that "population" is the most important element 
among others (Akira, 2007). The size of population is the determining factor in both the dimensions of the rise and maintenance of power (Kugler \& Tamen, 2004, p. 39). Accordingly, a militarist and contemporary security expert has concluded that no country would be able to rise to be a leading superpower without sufficient number of population. (Sandhu, 2009)

Although the size of population might be an essential factor, it is not necessarily the element that determines national power by itself alone (Jablonsky, 2010, p. 127). For instance, there is the huge size of Brazil, the industrial makeup of Belgium, or the first-class army of Switzerland, and the large population of Pakistan, yet none of these states is a first-rank power. (Jablonsky, 2010, p. 124)

Kowit Wongsurawat (2007, p. 147; 2011, p. 129), an expert on geopolitics in the Faculty of Political Science, Kasetsart University, has elaborated on this matter through the case studies of Japan and Israel. As for the first case, which has twice as much population as Thailand, populating a land where crucial natural resources are scarce and three-quarter the size of Thailand, yet Japan was able to progress to be the second most powerful economic superpower in the world. While the latter case, in the course of Arab-Israeli conflict, Israel was inferior in size of population, military strength, area, or even natural recourses, but gloriously win the war at the end of the day.

Thus proving that "quality" is of no less significance than "quantity" of population, agreeing with the conclusion of Sandhu (2009), an Indian militarist and security expert, which stated that, not just the quantity, but the quality of population also count as another potential factor that can deeply influence national power or capability as well.

\section{2. "Healthy/Unhealthy Conditions" of the "Population" of Thailand}

At the $2^{\text {nd }}$ Global international Studies Conference, Slovenia, 23-26 July, 2008, Hwang (2008, p. 11), a Ph.D. student from the German Institute of Global and Area Studies, University of Hamburg, Germany, summarised after analysing a huge number of factors of national strength, some of which have already been instanced earlier, that they could be reduce to four, defined by variables of qualitative/quantitative and mental/physical as per Table 1.

Table 1. Matrix of factors according to Hwang's concept

\begin{tabular}{lll}
\hline & Qualitative & Quantitative \\
\hline Mental & Character & Intelligence \\
Physical & Health & Wealth \\
\hline
\end{tabular}

Source: Hwang, 2008, p. 11.

By considering these factors, it is possible to say that the qualitative aspect of physical conditions of population, that is, "health", is a fundamental factor that is indispensable, since, on one hand, the flawlessness of this qualitative physical aspect, or health, can play a role in enabling other aspects to develop at maximum capacity. On the other hand, any flaw in this physical aspect can significantly affect the others, hindering the development of the other aspects or render them almost impossible to do so (Wongsurawat, 2011, p. 32), as evident from the catchphrase "healthy mind in a healthy body" (Wongsurawat, 2007, p. 146).

However, the survey report of Ministry of Health B.E. 2555 has revealed unhealthy conditions of Thai people in the present; shifted from causes of non-communicable diseases to suffer from lifestyle diseases more. (Sueluerm, Suthisukon, \& Dammee, 2008, p. 173). The number of population who were overweight to obese was over 17 million, ranked the 5th in the region of Asia-Pacific, and among those, there were around 4 million of children and adults who became fat each year on average, and approximately 20,000 died from obesity per year (Bangkok Biz News, 2012).

Consistent with Statistics of Obesity in Thailand publicised by International Anti-Aging Institute, Thailand Centre of Excellence for Life Sciences, Ministry of Science and Technology, on $6^{\text {th }}$ February, 2013, which highlighted the surge of a fifth of population (Thairath Online, 2013), causing the government's healthcare spending to exceed 100,000 million baht per annum. (Manager Online, 2012)

Since it is a disease caused by eating habits, public policies under the Ministry of Health, the programme "Thailand's Health Promotion" (Sueluerm, Suthisukon, \& Dammee, 2008, p. 173), for instance, have thus focused on instructing people to employ a habit-changing practice called the "3 Dos" which are food, mood, and exercise and "2 Don'ts" which are don't drink, and don't smoke (Manager Online, 2012). 
Speaking of "exercising", the result of a study by National Statistical Office in 2011 has revealed the trend of relationship between lack of exercise and illness and hospitalization; observable in population over 11 years old, 57.7 million in total, in a period of one month, 17.1 million had suffered from an illness, and among these, as high as $73.1 \%$ had not exercised in a month's time. Similarly to the number of people who had been hospitalised during a period of twelve months prior to the interview date, or a total of 3.1 million, and among these, as high as $76.0 \%$ had been short of exercise for a month. (Table 2)

Table 2. Statistic of exercising/lack of exercising and hospitalisation/non-hospitalisation of population suffered an illness and over 11 years old

\begin{tabular}{lllll}
\hline \multicolumn{2}{l}{$\begin{array}{l}\text { Sick population over 11 years old } \\
\text { Not hospitalised }\end{array}$} & & Hospitalised & \\
Exercise & Qty. (thousand) & percentage & Qty. (thousand) & percentage \\
\hline Exercising & $4,595.5$ & 26.9 & 765.6 & 24.0 \\
Not Exercising & $12,514.7$ & 73.1 & $2,426.9$ & 76.0 \\
Total & $17,110.2$ & 100.5 & $3,192.6$ & 100.0 \\
\hline
\end{tabular}

Source: National Statistical Office, 2011, p. 3.

The very same report by National Statistical Office (2011, p. 3) has also distinguished that, among those over 11 years old who exercised of 15.1 million, a little over a third were those who "played sports" $(34.7 \%$ or approximately 5.24 million), while the rest $(65.3 \%$ or approximately 9.86 million) exercised by different methods, such as, walking, running, equipment, dancing, yoga, and so on.

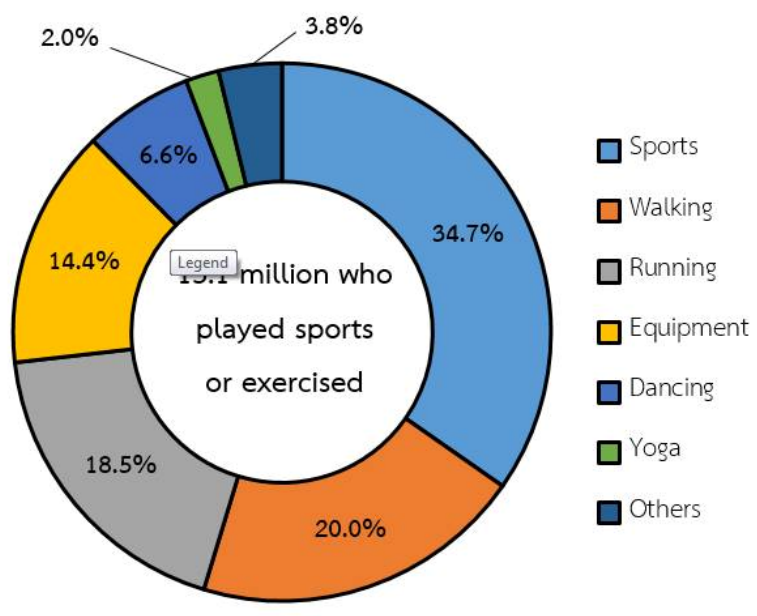

Figure 1. Percentage of population over 11 years old who exercised by category

Source: National Statistical Office, 2011, p. 3.

Comparing the proportions of the population who were obese, particularly children, the result of a survey by Malin Julsiri, an emerita professor in the Faculty of Pharmacy, Mahidol University, back in 2012 has stressed that the number had rapidly grown over the past decade, and most importantly, it was a rise at the fastest rate in the world. Still, it was projected that the surge would likely to continue. (Chanteerawong, 2012)

Likewise, the report of Department of Health, Ministry of Public Health, already explained earlier that the proportion of children from new-born to 12 years old being obese had risen by $40 \%$, followed by that of the age group of 40-50 years old being obese which had increased by almost twice as much, and that of the age group of 20-29 years which had a proportion of $21.7 \%$, agreeing with the medical data published by the Diabetes Association of Thailand under the Patronage of Her Royal Highness Princess Maha Chakri Sirindhorn, which clearly indicated that, in a period of five years, the number of Thai children below 15 years old who became diabetic had shifted from $2 \%$ to $12 \%$, exposed to liver diseases, heart diseases, arthritis (Krobkruakao, 2012) and particularly, affecting the development of intelligence (Chanteerawong, 2012). 
Therefore, it is noteworthy that these unhealthy conditions due to lack of exercise might already have affected Thailand's national power quite noticeably to some degree, at the very least, the national power in the aspect of sports through Thailand's share of medals in Asian Games throughout the last four decades;

By observing the unhealthy conditions which tend to intensify, contrary to Thailand's share of medals of Asian Games, whether gold, silver, bronze, or even the total count, which in overall, could be said that it has been on a decreasing trend, from a peak at $9.133 \%$ (39 of 427 medals) in the $6^{\text {th }}$ Asian Games on 9-20 December, 1970, to a mere $3.297 \%$ (52 of 1,577 medals) in the $16^{\text {th }}$ Asian Games on 12-27 November, 2010.

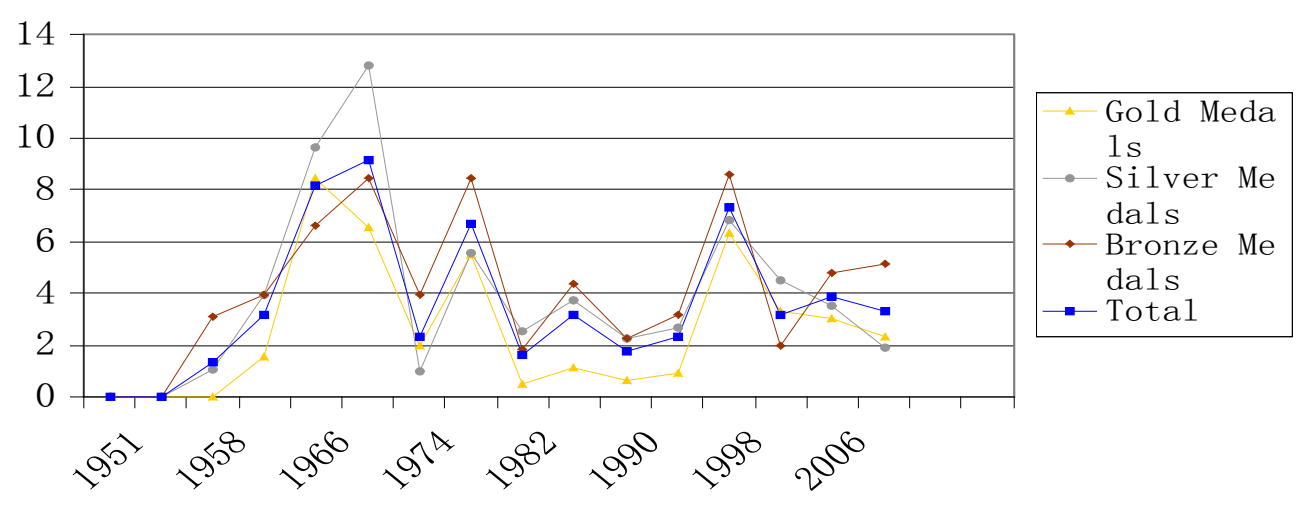

Figure 2. Thailand's share of medals in 1951-2010 Asian games

Source: Calculated and formatted by the authors from Wikipedia, 2012a, 2012b, 2012c, 2012d, 2012e, 2012f, 2012h, 2012i, 2012j, 2012k, 2012l, 2012m, 2012n, 2012p, 2012q, 2012r

\section{Experience of "Professional Standards for Sport Coaches" from Foreign Countries}

"Professional Standard" or "มาตรฐานวิชาชีพ" in Thai language was constructed by putting the word “มาตรฐาน" (Standard); something considered by general consent to be a basis for comparison, both in terms of quantitative and qualitative values (Royal Institute of Thailand, 1999a), between practices as the minimum level of acceptable performance. (College of Registered Nurses of British Columbia, 2012, p. 4).

Together with the word “วิชาชีพ” (Profession) or body of knowledge that would be used to earn a living, such as law, carpentry, mechanics (Royal Institute of Thailand, 1999b), which one who carries out a profession should have specialised trainings (Akaravaborn, 1999) which, according to Preedee Kasemsup (cited in Panyathai, n. d.), a professor specialised in civil law and philosophy of law from Thammasat University, require years and lifelong dedication. That is why there must be communities or groups that have traditional customs are mindful of the code of conduct, honour, and dignity, along with organisations and procedures to monitor, protect, and preserve such code, honour, and dignity as well.

That is to say, professional standard is the minimum acceptable standards of body of knowledge, skills, values, attitudes, ethics, rights, privileges, and obligations of a profession (Teachers Registration Council of Nigeria, 2010 , p. 2) formulated to promote and to use to as a guideline on how to practice such profession (College of Registered Nurses of British Columbia, 2012, p. 5) so as to maintain quality therein (Jampa, 2011, p. 2). Anyhow, the Teachers and Educational Personnel Council Act B.E. 2546 (2003) has been prescribed under Section 49 that professional standards (for teachers and educational personnel) consist of standards of professional knowledge and experience, standards of performance, and standards of conduct.

As for "professional standards for sport coaches", while Thailand's Department of Physical Education, Ministry of Tourism and Sports, is still in developmental stages of such, having football (Jampa, 2011) as an instance, experiences from foreign countries, particularly those of sporting superpowers; Australia and the United States of America, respectively, which may share common grounds, but still hold some remarkable distinctions that should be brought up as case studied and analysed in order to lay down a guideline for development, for the sake of population potential, sporting circle, as well as power of the nation in due course.

Under similar state of crisis to Thailand, that is, having the fifth highest rate of adult obesity in the developed world, accompanied by the result of the National Health Survey 2007-2008 uncovering that $68 \%$ of male adult 
and $55 \%$ of female adult were overweight or obese. Further, $17 \%$ of Australian children (5-17 years) were overweight and nearly 8\% were obese. (Australian Bureau of Statistics, 2009 cited in Commonwealth of Australia, 2010, p. 1);

Consequently, in 2010, the Commonwealth of Australia (2010) published a book "Australian Sport: The Pathway to Success" as a guideline to root out such problems in a sustainable fashion with the cooperation among various sections of the government, from Central Government to State Governments, local administrations, any other institutions, or organisations receiving budget supports from the government, through to educational institutes and communities under administration of federal government.

Starting by establishing a mutual recognition on the real condition of the problems, the traditional approach to which the government once adhered, that is, focusing on excellence or success in international sporting competitions through a "top down" approach to sport, which have served them well, with innovative systems and practices, Australia was thus able to "punch above their weight".

And multiply their share of medals in Summer Olympics over the past four decades, from $2.833 \%$ (17 of 600 medals) in the $20^{\text {th }}$ Summer Olympics on 26 August to 10 September, 1972 (Wikipedia, 2012g) to $6.257 \%$ (58 of 927 medals), only superseded by USA, Russia, and China, in the $27^{\text {th }}$ Summer Olympics, which was hosted by Australia, on 15 September to 1 October, 2000 (Wikipedia, 2012o).

However, the problem of unhealthy conditions of Australians, which had prompted the government to face the challenge of being unable to keep up with the pace of development compared to competing nations until Australia lost its leading competitive position in a short amount of time, demanded for a sport approach "from grassroots up", which placed a strategic focus on collaboration, reform, and investment extensively.

The extensive efforts to increase "opportunities" for all Australians to "participate" in sports, including children, disables, and women, were not limited to support through educational system or building more sporting grounds, but also by breaking down barriers to such participation for sections that once were not considered high-performance in sport, under aforementioned developmental strategy as the second stage of the reform;

Before strengthening sporting pathways, e.g., supporting volunteers and community coaches and officials, the pursuit of excellence (again/later), especially on the international stage, by investing in funding support and care of high performance coaches and officials, as well as researches, innovations, tertiary education, and fight against illicit drugs in sport.

In the case of Australia, although there has not yet been any professional standards for sport coaches sanctioned, the federal government's approach explicitly specified in "Australian Sport: The Pathway to Success" that the new strategy took a "holistic approach" to the sporting system that aimed at strengthening sport as a whole, not just the elite class who only focused on excellence, and so it has been embedded in the "National Professional Standards for Teachers", instructing physical education teachers under the "National Partnership for Improving Teacher Quality" to start carrying out the duty to foster quality sport as well as strengthen the system of physical education in schools.

Very dissimilar to the case of USA on the concept "Quality Coaches, Quality Sports" in the role of superpowers in almost every dimensions, even in aspect of sport, USA is one of a few countries that have enforced "national professional standards for sport coaches" extensively and officially. The latest edition of national professional standards for sport coaches has been published as "Quality Coaches, Quality Sports: National Standards for Sport Coaches" by National Association for Sport and Physical Education (2006), and republished the 2nd edition in 2006.

Under the objective to improve the quality of programmes and instructions by presenting guidelines to provide quality training that will have a positive impact on coaches' performance, to establish benchmarks for hiring quality coaches, and to provide a performance guide for individual professional growth and skill development to general audience.

The National Standards for Sport Coaches by National Association for Sport and Physical Education, USA, has been divided into 40 national standards under 8 domains, which are:

Domain 1: Philosophy and Ethics, consists of Standards 1 through 4 which clearly articulate the importance of an athlete-centred coaching philosophy and professional accountability for fair play by all.

Domain 2: Safety and Injury Prevention, consists of Standards 5 through 11 which establish expectations for coaches to create and maintain a safe and healthy sport experience for all athletes.

Domain 3: Physical Conditioning, consists of Standards 12 through 15 which highlight the importance of using 
scientific principles in designing and implementing conditioning programs for natural performance gains. Specific attention is given to body composition and weight management issues as well as awareness of contraindicated activities and over-training concerns. The important role physical conditioning plays in preventing and recovering from injuries is also included.

Domain 4: Growth and Development, consists of Standards 16 through 18 and related benchmarks clearly identify developmental considerations in designing practice and competition to enhance the physical, social, and emotional growth of athletes. Included in this area is the identification of the coach's role in creating an inclusive learning environment that leads all athletes to feel welcome and supported and to have experiences that foster leadership skills.

Domain 5: Teaching and Communication, consists of Standards 19 through 26 in which responsibilities for creating a positive coaching style while maximizing learning and enjoyment are established. Emphasis is placed on individualizing instruction, empowering communication skills, and using good management techniques in designing practices. This domain also includes benchmarks that make coaches aware of their role in mitigating bullying and harassment in the sport environment.

Domain 6: Sport Skills and Tactics, consists of Standards 27 through 29 which focus on using basic sport skills and acceptance of prescribed rules in developing team and individual competitive tactics. Emphasis is placed on planning that is age appropriate, sequential, and progressive. Benchmarks highlight the coach's role in making tactical and personnel decisions during competition. Domain 6 also includes definitive expectations for scouting and game analysis.

Domain 7: Organization and Administration, consists of Standards 30 through 36 which include risk management responsibilities as well as effective use of human and financial resources. Coaches play an important role in sharing administrative duties with any number of other stakeholders in maximizing the sport experience.

Domain 8: Evaluation, consists of Standards 37 through 40 which identify the ongoing evaluation responsibilities of the coach in areas such as personnel selection, on-time reflection of practice effectiveness, progress toward individual athlete goals, game management, and program evaluation. Creating a meaningful evaluation process for self-reflection and professional growth is also included in this area.

\section{Proposal on the Approach to Elevate "Professional Standards for Sport Coaches" in Thailand}

It is fairly evident that the ultimate aim of sport development, whether in the case of Australia which procedurally might just be to deliver sport for mass by focusing on developing from grassroots along with strengthening other bodies so as to facilitate sport, providing opportunities for the mass to participate in sport as widely as possible, and using the enforcement of "National Professional Standards for Teachers" to render physical education teachers to play a role of government's mechanism to foster quality sport as well as strengthening physical education right form school level for sport to excel at the international level and obtain sustainable success like USA.

The only different is how Australia positioned itself in terms of national sporting power as it was "punching above their weight". The successes achieved over decades, at the least, when considering the share of medals in Summer Olympics which had been on a rising trend continuously, contrariwise to the quality of population in aspect of health, unintentionally inhibited by top-down sport development approach which focused on the elite class in sports but marginalised other segments like children, people with disability, and women, and made them suffer from unhealthy conditions at a critical degree.

Unhealthy conditions of the population as such made Australian Federal Government realise that it might eventually impact competitiveness' sustainability to an extent that Australia would lose its position as a sport superpower, contrary to USA, which continued to develop sport to achieve excellence as days go by, specifically when looking at the National Standards for Sport Coaches still in use today, which emphasises on directing coaches' attention to athletes, so as to impart professionalism upon athletes, as well as driving them to success at the international level.

As for Thailand, professional standards (required procedures that probably reflect a duty or obligation for standard of care (Eickhoff-Shemek, 2001)) for sport coaches are yet to be officially realised, as they still are in developmental stages, and limited to football only. For as long as they have been produced during 2008-2012, they were merely "guides" (Note 1) (procedures that "should" be put into practise, developed for the purpose of augmenting the efficiency of management (Stone, 1998) without any legal status (Bunaramrueang, 2011, p. 173)) altogether. 
The strategy "Promote Health Together, for Healthy Thai, Strong Thailand" which has been declared as a national agenda by the order of prime minister since 2004, in physical aspect, the first objective aimed to promote exercising in every village, sub-district, community, agency, and establishment, and defined determinants and their purposes to get $60 \%$ of population over four years to exercise at least 30 minute a day for three days a week, by appointing the Ministry of Tourism and Sports, Ministry of Public Health, and Ministry of Education as the responsible party (Publication Department, 2004).

Together with the Five-Year Strategic Plan (B.E. 2554-2558 (2011-2015)) of the Department of Physical Education, Ministry of Tourism and Sports (2011e), the first strategic point; promotion and development of physical education, health, sport, recreation, and sports science, the first determinant; children, youths, and targeted groups of people regularly play sports and exercise, has specified the aim for $2011-2015$ that $85 \%$ of children, youths, and people of all target groups play sports and exercise regularly.

Taking into consideration the survey reports of Ministry of Science and Technology, National Statistical Office and the Diabetes Association of Thailand, as well as the study report of Mahidol University on Unhealthy Conditions in Aspect of Health of Population in Thailand, not only proven the failure of the aforesaid national agenda, but it has also been brought to light the possibility that the Five-Year Plan (B.E. 2554-2558) of the Department of Physical Education is likely to fail to be accomplished if there has not been any significant changes to take place.

The practice to fix such problems, which would directly influence potential of the population and the power of nation in due course, by definition of professional standards of superpowers, particularly as in the case of the Commonwealth of Australia, therefore, is a suitable approach which the agency holding direct responsibility and authority, or the Department of Physical Education, should consider utilising as a model, adapt, and officially put into effect.

Primarily, a consideration is given to the proposal from the research "A Development of Professional Standards of Football Coaches for Department of Physical Education" by Panupong Jampa (2011), a student in the Master of Science Programme in Sports Science, Faculty of Sports Science, Chulalongkorn University, which has synthesised and divided the professional standards of football coaches of the Department of Physical Education into three categories; standards of professional knowledge, standards of performance, and standards of conduct, and improved for more suitability, particularly for them to become national standards for sport coaches, so to speak.

Still, apart from the option to adopt and adapt the same approach as Australian's, by enforcing the abovementioned professional standards upon physical education teachers so as to foster quality sport and strengthen the body of physical education from school level.

Recreation specialists or local administration officials directly responsible for the development of projects/programmes and recreational activities that would encourage students, youngsters, elders, and general population to spend their free time for good causes and good health conditions, e.g., sport competition programmes, physical activity promotion projects, and sport skills training programmes (Thailand Innovative Administration Consultancy Institute, 2010, p. 387) are another option, as they are public mechanism already in existence and also are closest to the people.

The mission of public agencies, especially the Department of Physical Education, to realise sport for the mass extensively would thus prove to be a crucial challenge in the face of crisis, as they are the providers of benchmarking and trainings for physical education teachers and recreation specialists, including other mechanisms, of the entire country for the ability to encourage people to be confident (Teaching Australia, 2008, p. 4), to be aware of the advantages of having a good health, and to participate as extensively as possible, as well as being in accordance with the professional standards for sport coaches that may be enforced in the time yet to come.

Therefore, it is deemed necessary for the government to support both in terms of budgets and enactments of laws concerning the profession of sport coaches, like any other professions, to reinforce the power of this nation from the grassroots through the development of qualitative factors of the population, in order to prepare them for daily living in the modern time in a sustainable fashion thereafter. 


\section{References}

Akaravaborn, T. (1999). Teacherness. Bangkok: Polapim.

Akira, K. (2007). Population and National Power. Japan Echo, 34(4), 7-9.

Alcock, N., \& Newcombe, A. (1970). The Perception of National Power. Journal of Conflict Resolution, 14, 335-343. http://dx.doi.org/10.1177/002200277001400304

Bangkok Biz News. (2012). Pub Health Found 20,000 Thais a Year Died of Obesity. Retrieved from http://www.bangkokbiznews.com/home/detail/politics/life/20120802/464485/สธ.พบคนไทยตายเพราะโรคอ้ วนปีละ2หมื่นคน.html

Cangemi, J. (1992). Some Observations of Successful Leaders, and Their Use of Power and Authority. Education, (112), 499-505.

Chanteerawong, N. (2012). Worry about Thai Children-Stats "Obese" Rise the Highest; Impacting IQ-Lower than Standards, Soda Tax to Raise-School front Snacks to Be Banned. Retrieved from http://www.tcijthaicom/TCIJ/view.php?ids=1317

Claude, I. (1962). Power and International Relations. New York: Random House.

College of Registered Nurses of British Columbia. (2012). Professional Standards for Registered Nurses and Nurse Practitioners. Vancouver: College of Registered Nurses of British Columbia.

Commonwealth of Australia. (2010). Australian Sport: The Pathway to Success. Canberra: Commonwealth of Australia.

Couloumbis, T., \& Wolfe, J. (1982). Introduction to International Relations: Power and Justice (2nd ed.). New Jersey: Prentice Hall.

Davis, K. (1954). The Demographic Foundations of National Power. In M. Berger et al. (Eds.), Freedom and Control in Modern Society (pp. 206-242). New York: Farrar, Straus \& Giroux.

Deutsch, K. (1968). The Analysis of International Relations. New Jersey: Prentice Hall.

Eickhoff-Shemek, J. (2001). Standard of Practice. In D. Cotten, J. Wilde, \& J. Wlohan (Eds.), Law for Recreation\& Sport Managers (2nd ed., pp. 293-302). Iowa: Kendall/Hunt.

German, F. (1960). A Tentative Evaluation of World Power. Journal of Conflict Resolution, 4, 138-144. http://dx.doi.org/10.1177/002200276000400110

Hitch, C., \& McKean, R. (1960). The Economics of Defense in the Nuclear Age. Cambridge: Harvard University Press. http://dx.doi.org/10.4159/harvard.9780674865884

Hwang, K. (2008). New Thinking in Measuring National Power. (Paper prepared for the WISC Second Global International Studies Conference University of Ljubljana, Slovenia, 23-26 July 2008). Retrieved from http://www.wiscnetwork.org/ljubljana2008/papers/WISC_2008-137.pdf

Jablonsky, D. (2010). National Power. In J. Jr. Bartholomees (Ed.), Theory of War and Strategy (4th ed., Vol. 1, pp. 123-140). U.S. Army War College Guide to National Security Issues. Pennsylvania: Strategic Studies Institute, U.S. Army War College.

Jampa, P. (2011). A Development of Professional Standards of Football Coaches for Department of Physical Education. Thesis of Master of Science in Sports Science, Chulalongkorn University.

Krobkruakao. (2012). Pub Health Reveal Obesity Highest in Decade. Retrieved from www.krobkruakao.com/ข่าว/54106/สธ-เผยโรคอ้วนพุ่งสูงในรอบ-10-ปี.html

Kelly, P. (1984). Geopolitical Themes in the Writings of General Carlos de Meira of Brazil. Journal of Latin American Studies, 16(2), 439-461. http://dx.doi.org/10.1017/S0022216X00007136

Knorr, K. (1956). The War Potential of Nations. Princeton: Princeton University Press.

Kugler, J., \& Tamen, R. (2004). Regional Challenge: China's Rise to Power. In J. Rolfe (Ed.), The Asia-Pacific: A Region in Transition (pp. 33-53). Hawaii: Asia-Pacific Center for Security Studies.

Manager Online. (2012). Obese Thai Rank 5th Asia-Pacific. Retrieved from www.manager.co.th/QOL/ViewNews.aspx?NewsID=9550000090251

Ministry of Tourism and Sports. Department of Physical Education. (2008a). T-License Futsal Coaching Guide. Bangkok: Department of Physical Education, Ministry of Tourism and Sports.

Ministry of Tourism and Sports. Department of Physical Education. (2008b). T-License Speak Takraw Coaching Guide. Bangkok: Department of Physical Education, Ministry of Tourism and Sports.

Ministry of Tourism and Sports. Department of Physical Education. (2009a). Level 1 T-License Volleyball Coaching Guide. Bangkok: Department of Physical Education, Ministry of Tourism and Sports.

Ministry of Tourism and Sports. Department of Physical Education. (2009b). T-License Amateur Boxing Coaching Guide. Bangkok: Department of Physical Education, Ministry of Tourism and Sports. 
Ministry of Tourism and Sports. Department of Physical Education. (2009c). T-License Amateur Muaythai Coaching Guide. Bangkok: Department of Physical Education, Ministry of Tourism and Sports.

Ministry of Tourism and Sports. Department of Physical Education. (2009d). T-License Athletics Coaching Guide. Bangkok: Department of Physical Education, Ministry of Tourism and Sports.

Ministry of Tourism and Sports. Department of Physical Education. (2009e). T-License Football Coaching Guide. Bangkok: Department of Physical Education, Ministry of Tourism and Sports.

Ministry of Tourism and Sports. Department of Physical Education. (2009f). T-License Handball Coaching Guide. Bangkok: Department of Physical Education, Ministry of Tourism and Sports.

Ministry of Tourism and Sports. Department of Physical Education. (2009g). T-License Taekwondo Coaching Guide. Bangkok: Department of Physical Education, Ministry of Tourism and Sports.

Ministry of Tourism and Sports. Department of Physical Education. (2009h). T-License Weightlifting Coaching Guide. Bangkok: Department of Physical Education, Ministry of Tourism and Sports.

Ministry of Tourism and Sports. Department of Physical Education. (2010a). T-License Badminton Coaching Guide. Bangkok: Department of Physical Education, Ministry of Tourism and Sports.

Ministry of Tourism and Sports. Department of Physical Education. (2010b). T-License Basketball Coaching Guide. Bangkok: Department of Physical Education, Ministry of Tourism and Sports.

Ministry of Tourism and Sports. Department of Physical Education. (2010c). T-License Pétanque Coaching Guide. Bangkok: Department of Physical Education, Ministry of Tourism and Sports.

Ministry of Tourism and Sports. Department of Physical Education. (2011a). Five-Year Strategic Plan. Bangkok: Department of Physical Education, Ministry of Tourism and Sports.

Ministry of Tourism and Sports. Department of Physical Education. (2011b). T-License Dance Coaching Guide. Bangkok: Department of Physical Education, Ministry of Tourism and Sports.

Ministry of Tourism and Sports. Department of Physical Education. (2011c). T-License Karate-Do Coaching Guide. Bangkok: Department of Physical Education, Ministry of Tourism and Sports.

Ministry of Tourism and Sports. Department of Physical Education. (2011d). T-License Table Tennis Coaching Guide. Bangkok: Department of Physical Education, Ministry of Tourism and Sports.

Ministry of Tourism and Sports. Department of Physical Education. (2011e). T-License Wood Ball Coaching Guide. Bangkok: Department of Physical Education, Ministry of Tourism and Sports.

Ministry of Tourism and Sports. Department of Physical Education. (2012). T-Certificate Football Coaching Guide. Bangkok: Department of Physical Education, Ministry of Tourism and Sports.

Modelski, G., \& Thompson, W. (1987). Sea-power in Global Politics, 1494-1983. Seattle: University of Washington Press.

National Association for Sport and Physical Education. (2006). Quality Coaches, Quality Sports: National Standards for Sport Coaches (2nd ed.). Virginia: National Association for Sport and Physical Education.

National Statistical Office. (2011). Executive Summary: People's Sport and Physical Activity Behaviour Survey B.E. 2554. Retrieved from http://service.nso.go.th/nso/nsopublish/themes/files/exerExec54.pdf

Organski, A. (1958). World Politics. New York: Knopf.

Panyathai. (n. d.). Profession. Retrieved from http://www.panyathai.or.th/wiki/index.php/วิชาชีพ

Publication Department. (2004). Strategy "Promote Health Together, for Healthy Thai, Strong Thailand." Retrieved from http://advisor.anamai.moph.go.th/274/27401.html

Royal Institute of Thailand. (1999a). มัย ๒-มาราธิราช. Retrieved from http://rirs3.royin.go.th/word31/word-31-a6.asp

Royal Institute of Thailand. (1999b). วาสนะ ๒-วิธ วิธา. Retrieved from http://rirs3.royin.go.th/word37/word-37-a4.asp

Sandhu, P. (2009). National Power and Grand Strategy. AGNI, 12(3), 41-53.

Spanier, J., \& Wendzel, R. (1996). Games Nations Play (9th ed.). Washington D.C.: CQ.

Stone et al. (1998). Athletic Performance Development: Volume Load-1 Set vs. Multiple Sets, Training Velocity and Train Variation." Strength \& Conditioning, 20(6), 22-31. http://dx.doi.org/10.1519/1073-6840(1998)020<0022:APDVLS >2.3.CO;2

Sueluerm, K., Suthisukon, P., \& Dammee, D. (2008). People Development Orientation in Aspect of Health Promotion. Journal of Public Health and Development, 6(1), 171-176.

Teachers and Educational Personnel Council Act B.E. 2546.

Teachers Registration Council of Nigeria. (2010). Professional Standards for Nigerian Teachers. Retrieved from http://www.tren.gov.ng/PSNT\%202010.pdf 
Teaching Australia. (2008). National Professional Standards for Advanced Teaching and for Principals. Canberra: Teaching Australia.

Thailand Innovative Administration Consultancy Institute. (2010). Position Specification of Local Government Officials: Proceedings of the Final Reports on the Research Project on Improvement of the Local Government Official Position Classification and Compensation Management System of (Second Phase). Nonthaburi: Thailand Innovative Administration Consultancy Institute.

Thairath Online. (2013). Shock! 1/5 of Thai are Obese, Suggest Avoiding Fat on Chinese New Year. Retrieved from http://www.thairath.co.th/content/edu/325021

Warren, M. (1992). Max Weber's and Nietzschean Conception of Power. History of Human Sciences, 5(3), 19-37. http://dx.doi.org/10.1177/095269519200500303

Wikipedia. (2011). Principle of Political Science (4th ed.). Bangkok: Eastern.

Wikipedia. (2012a). 1951 Asian Games. Retrieved from http://th.wikipedia.org/wiki/เอเชียนเกมส์_1951

Wikipedia. (2012b). 1954 Asian Games. Retrieved from http://th.wikipedia.org/wiki/เอเชียนเกมส์_1954

Wikipedia. (2012c). 1958 Asian Games. Retrieved from http://th.wikipedia.org/wiki/เอเชียนเกมส์_1958

Wikipedia. (2012d). 1962 Asian Games. Retrieved from http://th.wikipedia.org/wiki/เอเชียนเกมส์_1962

Wikipedia. (2012e). 1966 Asian Games. Retrieved from http://th.wikipedia.org/wiki/เอเชียนเกมส์_1966

Wikipedia. (2012f). 1970 Asian Games. Retrieved from http://th.wikipedia.org/wiki/เอเชียนเกมส์_1970

Wikipedia. (2012g). 1972 Summer Olympics Medal Table. Retrieved from http://th.wikipedia.org/wiki/สรุปเหรียญโอลิมปิกฤดูร้อน_1972

Wikipedia. (2012h). 1974 Asian Games. Retrieved from http://th.wikipedia.org/wiki/เอเชียนเกมส์_1974 Wikipedia. (2012i). 1978 Asian Games. Retrieved from http://th.wikipedia.org/wiki/เอเชียนเกมส์_1978 Wikipedia. (2012j). 1982 Asian Games. Retrieved from http://th.wikipedia.org/wiki/เอเชียนเกมส์_1982 Wikipedia. (2012k). 1986 Asian Games. Retrieved from http://th.wikipedia.org/wiki/เอเชียนเกมส์_1986 Wikipedia. (20121). 1990 Asian Games. Retrieved from http://th.wikipedia.org/wiki/เอเชียนเกมส์_1990 Wikipedia. (2012m). 1994 Asian Games. Retrieved from http://th.wikipedia.org/wiki/เอเชียนเกมส์_1994 Wikipedia. (2012n). 1998 Asian Games. Retrieved from http://th.wikipedia.org/wiki/เอเชียนเกมส์_1998

Wikipedia. (20120). 2000 Summer Olympics Medal Table. Retrieved from http://th.wikipedia.org/wiki/สรุปเหรียญโอลิมปิกฤดูร้อน_2000

Wikipedia. (2012p). 2002 Asian Games. Retrieved from http://th.wikipedia.org/wiki/เอเชียนเกมส์_2002

Wikipedia. (2012q). 2006 Asian Games. Retrieved from http://th.wikipedia.org/wiki/เอเชียนเกมส์_2006 Wikipedia. (2012r). 2010 Asian Games. Retrieved from http://th.wikipedia.org/wiki/เอเชียนเกมส์_2010

Wikipedia. (2012s). All-time Asian Games Medal Table. Retrieved from http://th.wikipedia.org/wiki/สรุปเหรียญเอเชียนเกมส์

Wongsurawat, K. (2007). Geopolitics. Bangkok: Wassana.

\section{Note}

Note 1. Namely T-Licence Futsal Coaching Guide (Department of Physical Education, Ministry of Tourism and Sports, 2008a), T-Licence Sepak Takraw Coaching Guide (Department of Physical Education, Ministry of Tourism and Sports, 2008b), Level 1 T-Licence Volleyball Coaching Guide (Department of Physical Education, Ministry of Tourism and Sports, 2009a), T-Licence Amateur Boxing Coaching Guide (Department of Physical Education, Ministry of Tourism and Sports, 2009b), T-Licence Amateur Muaythai Coaching Guide (Department of Physical Education, Ministry of Tourism and Sports, 2009c), T-Licence Athletics Coaching Guide (Department of Physical Education, Ministry of Tourism and Sports, 2009d), T-Licence Football Coaching Guide (Department of Physical Education, Ministry of Tourism and Sports, 2009e), T-Licence Handball Coaching Guide (Department of Physical Education, Ministry of Tourism and Sports, 2009f), T-Licence Taekwondo Coaching Guide (Department of Physical Education, Ministry of Tourism and Sports, 2009g), T-Licence Weightlifting Coaching Guide (Department of Physical Education, Ministry of Tourism and Sports, 2009h), T-Licence Badminton Coaching Guide (Department of Physical Education, Ministry of Tourism and Sports, 2010a), T-Licence Basketball Coaching Guide (Department of Physical Education, Ministry of Tourism and Sports, 2010b), T-Licence Pétanque Coaching Guide (Department of Physical Education, Ministry of Tourism and Sports, 2010c), T-Licence Dance Coaching Guide (Department of Physical Education, Ministry of Tourism and Sports, 2011b), T-Licence Karate-Do Coaching Guide (Department of Physical Education, Ministry of 
Tourism and Sports, 2011c), T-Licence Table Tennis Coaching Guide (Department of Physical Education, Ministry of Tourism and Sports, 2011d), T-Licence Wood Ball Coaching Guide (Department of Physical Education, Ministry of Tourism and Sports, 2011e), and T-Certificate Football Coaching Guide (Department of Physical Education, Ministry of Tourism and Sports, 2012)

\section{Appendix}

Appendix: Thailand's Asian games medal count and share 1951-2010

\begin{tabular}{|c|c|c|c|c|c|}
\hline Games & Year & $\begin{array}{l}\text { Gold } \\
(\%)\end{array}$ & $\begin{array}{l}\text { Silver } \\
(\%)\end{array}$ & $\begin{array}{l}\text { Bronze } \\
(\%)\end{array}$ & $\begin{array}{l}\text { Total } \\
(\%)\end{array}$ \\
\hline 1 & 1951 & $\begin{array}{l}0 / 57 \\
(0.000 \%)\end{array}$ & $\begin{array}{l}0 / 55 \\
(0.000 \%)\end{array}$ & $\begin{array}{l}0 / 55 \\
(0.000 \%)\end{array}$ & $\begin{array}{l}0 / 169 \\
(0.000 \%)\end{array}$ \\
\hline 2 & 1954 & $\begin{array}{l}0 / 75 \\
(0.000 \%)\end{array}$ & $\begin{array}{l}0 / 74 \\
(0.000 \%)\end{array}$ & $\begin{array}{l}0 / 69 \\
(0.000 \%)\end{array}$ & $\begin{array}{l}0 / 218 \\
(0.000 \%)\end{array}$ \\
\hline 3 & 1958 & $\begin{array}{l}0 / 110 \\
(0.000 \%)\end{array}$ & $\begin{array}{l}1 / 94 \\
(1.064 \%)\end{array}$ & $\begin{array}{l}3 / 98 \\
(3.061 \%)\end{array}$ & $\begin{array}{l}4 / 302 \\
(1.325 \%)\end{array}$ \\
\hline 4 & 1962 & $\begin{array}{l}2 / 127 \\
(1.575 \%)\end{array}$ & $\begin{array}{l}5 / 126 \\
(3.968 \%)\end{array}$ & $\begin{array}{l}5 / 128 \\
(3.906 \%)\end{array}$ & $\begin{array}{l}12 / 381 \\
(3.150 \%)\end{array}$ \\
\hline 5 & 1966 & $\begin{array}{l}12 / 142 \\
(8.451 \%)\end{array}$ & $\begin{array}{l}14 / 145 \\
(9.655 \%)\end{array}$ & $\begin{array}{l}11 / 167 \\
(6.587 \%)\end{array}$ & $\begin{array}{l}37 / 454 \\
(8.150 \%)\end{array}$ \\
\hline 6 & 1970 & $\begin{array}{l}9 / 137 \\
(6.569 \%)\end{array}$ & $\begin{array}{l}17 / 133 \\
(12.782 \%)\end{array}$ & $\begin{array}{l}13 / 154 \\
(8.442 \%)\end{array}$ & $\begin{array}{l}39 / 427 \\
(9.133 \%)\end{array}$ \\
\hline 7 & 1974 & $\begin{array}{l}4 / 200 \\
(2 \%)\end{array}$ & $\begin{array}{l}2 / 198 \\
(1.010 \%)\end{array}$ & $\begin{array}{l}8 / 203 \\
(3.941 \%)\end{array}$ & $\begin{array}{l}14 / 601 \\
(2.329 \%)\end{array}$ \\
\hline 8 & 1978 & $\begin{array}{l}11 / 201 \\
(5.473 \%)\end{array}$ & $\begin{array}{l}11 / 198 \\
(5.556 \%)\end{array}$ & $\begin{array}{l}20 / 226 \\
(8.450 \%)\end{array}$ & $\begin{array}{l}42 / 625 \\
(6.720 \%)\end{array}$ \\
\hline 9 & 1982 & $\begin{array}{l}1 / 199 \\
(0.503 \%)\end{array}$ & $\begin{array}{l}5 / 200 \\
(2.500 \%)\end{array}$ & $\begin{array}{l}4 / 215 \\
(1.860 \%)\end{array}$ & $\begin{array}{l}10 / 614 \\
(1.629 \%)\end{array}$ \\
\hline 10 & 1986 & $\begin{array}{l}3 / 270 \\
(1.111 \%)\end{array}$ & $\begin{array}{l}10 / 268 \\
(3.731 \%)\end{array}$ & $\begin{array}{l}13 / 299 \\
(4.348 \%)\end{array}$ & $\begin{array}{l}26 / 837 \\
(3.144 \%)\end{array}$ \\
\hline 11 & 1990 & $\begin{array}{l}2 / 310 \\
(0.645 \%)\end{array}$ & $\begin{array}{l}7 / 309 \\
(2.265 \%)\end{array}$ & $\begin{array}{l}8 / 357 \\
(2.241 \%)\end{array}$ & $\begin{array}{l}17 / 975 \\
(1.744 \%)\end{array}$ \\
\hline 12 & 1994 & $\begin{array}{l}3 / 335 \\
(0.896 \%)\end{array}$ & $\begin{array}{l}9 / 335 \\
(2.687 \%)\end{array}$ & $\begin{array}{l}13 / 411 \\
(3.163 \%)\end{array}$ & $\begin{array}{l}25 / 1,069 \\
(2.339 \%)\end{array}$ \\
\hline 13 & 1998 & $\begin{array}{l}24 / 379 \\
(6.332 \%)\end{array}$ & $\begin{array}{l}26 / 381 \\
(6.824 \%)\end{array}$ & $\begin{array}{l}40 / 467 \\
(8.565 \%)\end{array}$ & $\begin{array}{l}90 / 1,227 \\
(7.335 \%)\end{array}$ \\
\hline 14 & 2002 & $\begin{array}{l}14 / 427 \\
(3.279 \%)\end{array}$ & $\begin{array}{l}19 / 421 \\
(4.513 \%)\end{array}$ & $\begin{array}{l}10 / 502 \\
(1.992 \%)\end{array}$ & $\begin{array}{l}43 / 1,350 \\
(3.185 \%)\end{array}$ \\
\hline 15 & 2006 & $\begin{array}{l}13 / 428 \\
(3.037 \%)\end{array}$ & $\begin{array}{l}15 / 423 \\
(3.546 \%)\end{array}$ & $\begin{array}{l}26 / 542 \\
(4.797 \%)\end{array}$ & $\begin{array}{l}54 / 1,393 \\
(3.877 \%)\end{array}$ \\
\hline 16 & 2010 & $\begin{array}{l}11 / 477 \\
(2.306 \%)\end{array}$ & $\begin{array}{l}9 / 479 \\
(1.879 \%)\end{array}$ & $\begin{array}{l}32 / 621 \\
(5.153 \%)\end{array}$ & $\begin{array}{l}52 / 1,577 \\
(3.297 \%)\end{array}$ \\
\hline Total & & $\begin{array}{l}109 / 3,847 \\
(2.833 \%)\end{array}$ & $\begin{array}{l}148 / 3,839 \\
(3.855 \%)\end{array}$ & $\begin{array}{l}206 / 4,514 \\
(4.564)\end{array}$ & $\begin{array}{l}463 / 12,219 \\
(3.789 \%)\end{array}$ \\
\hline
\end{tabular}

Source: Calculated and formatted by the authors from Wikipedia, 2012a, 2012b, 2012c, 2012d, 2012e, 2012f, 2012h, 2012i, 2012j, 2012k, 20121, 2012m, 2012n, 2012p, 2012q, 2012r

\section{Copyrights}

Copyright for this article is retained by the author(s), with first publication rights granted to the journal.

This is an open-access article distributed under the terms and conditions of the Creative Commons Attribution license (http://creativecommons.org/licenses/by/3.0/). 